\title{
INDONESIAN PORTRAYED IN ENGLISH GENRE TEXTS: A STUDENT'S WORKSHEET ANALYSIS
}

\author{
Lilik Tri Mulyani \\ State University of Surabaya, Indonesia \\ liliktrie.lt@gmail.com
}

\begin{abstract}
Indonesia, from Sabang to Merauke, has thousands of archipelagos which lead it to have cultural diversity. Recognizing its huge diversity is important to build the national unity. One of the ways is through education. In fact, National Examination is stated as the benchmark to the national educational equality. This paper aimed to analyze the Indonesian local wisdom written in the English genre text in the student's national examination preparation. It deals with the brief description about the content of the student's worksheet, titled Prediksi UN SMP Bahasa Inggris published by Graha Pustaka Jakarta Indonesia. This is a descriptive research which the student's worksheet is as the main data. It becomes one of students' compulsory books for one of Junior High school in Jombang, East Java in facing National Examination. The result shows that there are 5 text types provided; Descriptive, Procedure, Narrative, Recount and Report. From the text types above, there are $18 \%$ texts which describe/ tell about the how Indonesia is described through the description (Descriptive and Recount text ), and folklore (Narrative). The descriptions will make students more recognize and love Indonesia through its diversity (e.g. Monumen Nasional, Ari's Grandmother, etc, and the story can be learnt its moral value (e.g. the history of Cenderawasih, etc) to be applied in daily life. Finally, the researcher hopes that this research gives big contribution to all the readers particularly for the publishers to select the text with the Indonesian local wisdom so that the students will have high awareness and love to their nation.
\end{abstract}

Keywords: cultural diversity, unity, national examination preparation, English genre texts, descriptive research

\section{INTRODUCTION}

"Indonesia ialah Negara Kesatuan yang berbentuk Republik" (UUD 1945 Pasal 1 ayat 1), Indonesia is a Republic Unitary Nation (Indonesian Constitution 1945 subsection 1:1). It indicates that there are lots of diversity which is united. In fact, Indonesia consists of about 17.508 islands which form thousands of cultures, tradition, languages, arts and so forth. These diversities create many problems nowadays. The issue of SARA (Suku, Agama, Ras dan Antar golongan), (ethnicity, religion, ancestry, and group of people) is mostly appeared to destruct the Indonesian peace. The newest chaos was the political issue in Jakarta general election (Ardian Wiwaha on Kompasiana, November $4^{\text {th }} 2016$ ). This issue leads to the problem on Indonesian education. Students reject the leader of OSIS (school organization) because they have different religion, (Henny Supolo Sitepu, education activist, Thursday, May $2^{\text {nd }} 2017$ via Metrotvnews.com. Integrated awareness through education is necessarily built to decrease the problem. Local wisdom is as the moral value which is used to describe, explain and or maintain culture through education.

National examination (UNAS) is stated as the benchmark to the Indonesian educational equality. The examination points and competence are the same although the questions provided are different based on the sub Education area. For 
both Junior and Senior High school students, English becomes one of the lessons examined in the National examination. Based on the 2013 curriculum, there are 2 big competences included, functional text and genre texts; Descriptive, Procedure, Narrative, Recount and Report. Learn English, students also learn its culture. As the result, the balance between cultural element in language used (Bahasa Indonesia) and language learnt (English) written for students, is important. The insertion of Indonesian description and culture in English genre texts will help students to have higher awareness to their nation, Indonesia. In this paper, the researcher is interested in analyzing Indonesian local wisdom portrayed in English Genre Texts in Student's worksheet of National examination preparation test.

\section{LITERATURE REVIEW}

\subsection{Local wisdom}

Local wisdom is composed from 2 words, local and wisdom. Local is relating or restricted to a particular area or one's neighborhood (Oxford Dictionary). While wisdom or sapience is the ability to think and act using knowledge, experience, understanding, common sense, and insight (Wikipedia). Local wisdom is basic knowledge gained from living in balance with nature. It is related to culture in the communitywhich isaccumulated andpassed on. Thiswisdom can be both Abstract and concrete,but the important characteristics are that it comes from experiences or truth gained from life. The wisdom from realexperiences integrates the body, the spirit and the environment. It emphasizes respect for elders and their life experiences. Moreover, it values morals more than material things (Nakorntap et. al., 1996). To sum up with, local wisdom is a cultural value from the particular society. It taught the society to have good things in their live.

Local wisdom is observed from the society's behavior. It is seen from the local norms, local ritual or tradition, local history and or folklore which contain moral values, information and knowledge explained by local elders, manuscript, how the community fulfills their life, properties used and also the natural resources utilized in the society in daily life (Sartini, 2004). The purpose of local wisdom in education is to built the students characters as what supported by the Government. Beside that, the insertion is beneficial to introduce and also maintain cultural value.

2.2 English genre texts

There are for about 13 English genre texts learnt by the students of Junior up to Senior High School. For Junior High, there are 5 genres learnt; Descriptive, Procedure, Narrative, Recount and Report.

a. Descriptive text is a text which describes objects (someone or something). The purpose of the text is to give detailed description. The structures of the text are identification and description.

b. Procedure text is a text which tells how to do something. The purpose of the text is to give direction to the reader by giving some sequences. The structures of the text are goal, materials and steps.

c. Narrative text is a text which tells actions in sequenced. The purpose of the text is to entertain the readers. The structures of the text are orientation, complication, re orientation. This text mostly gives moral value to the readers.

d. Recount is a text which retells the action happen. It uses past time. The purpose of the text is to entertain the readers about someone's experience. The structures of the text are orientation, events and reorientation. 
e. Report text is a text which describes objects (someone or something) in general. The purpose of the text is to give general description. The structures of the text are general classification and description. (English First)

2.3 Achievement test

There are 5 kinds of tests stated by Brown, (2000: 390). They are proficiency test, diagnostic test, placement test, achievement test and aptitude test. An achievement test is related directly to classroom lesson, units, or even a total curriculum. The purpose of this test is to know the students' achievement of the course objectives at the end of period of instruction. In Indonesia, UNAS is one of achievement test which is done in the end of the school period (end of Junior and Senior High School). This examination is done at the same time in all parts of Indonesia.

\section{METHODS}

This is a descriptive qualitative research. Maxwell (2005) cited in Ary et, al (2010: 426) discusses researcher goals for which he believes qualitativestudies are especially suited: understanding meaning for the participants, understanding a particular context, identifying unanticipated phenomena andinfluences through which new theories may be generated, understanding process, and developing causal explanations (though he recognizes the disputeinherent when considering the more traditionalist research views). This research focuses on the student's worksheet analysis. It deals with the analysis on the 5 text types which contain Indonesian context/ local wisdom. The data is taken from the student's national examination preparation book titled Prediksi UN SMP Bahasa Inggris published by Graha Pustaka Jakarta Indonesia. First, the researcher finds out the text types written in the book. Then they are classified into the 5 text types which are learnt by Junior High School students. All texts are identified which contain the Indonesian describing and also its local wisdom. The researcher counts the percentage by: The text which contain Indonesian Description and its local wisdom x 100\%

All text provided

\section{FINDINGS AND DISCUSSION}

The book titled Prediksi UN SMP Bahasa Inggris published by Graha Pustaka Jakarta contains 128 sheets. There are acknowledgement, table of content, blue print, the summary of English material, 4 files for exercise and 4 files for UNAS prediction test. All files contain 5 functional texts and 5 text types. But this research focuses on the 5 text types only. There are totally 97 texts; 32 texts for Descriptive, 18 texts for Procedure, 15 texts for Narrative, 25 texts for Recount and 17 texts for Report text. Some texts describe some people and places in Indonesia and also tell narrative and or folklore which contain moral value. Here is the following explanation:

\subsection{Description}

The book gives some description about some places in Indonesia. This can introduce Indonesia's beauty. The value through learning this point is that it leads the students to recognize the diversity and love the country. These descriptions included into the descriptive texts. Other descriptions are in the form of Recount text (experience in going some places in Indonesia) 


\begin{tabular}{|c|c|c|c|}
\hline Title & Sentence/ paragraph & The text is about & Text type \\
\hline $\begin{array}{l}\text { Ari's grandmother } \\
\text { p. } 18\end{array}$ & $\begin{array}{l}\text { Ari's grandmother is a } \\
\text { very gentle, loving, and } \\
\text { caring person. She never } \\
\text { raises her voice at } \\
\text { anyone..... }\end{array}$ & $\begin{array}{l}\text { The text } \\
\text { describes how } \\
\text { Ari's } \\
\text { grandmother } \\
\text { who is like } \\
\text { typically } \\
\text { Indonesia people } \\
\text { who are known } \\
\text { as kind people. }\end{array}$ & Descriptive \\
\hline $\begin{array}{l}\text { My Holiday in Bali } \\
\text { p. } 24\end{array}$ & $\begin{array}{l}\text {...the journey from Pati } \\
\text { to Bali took one day....all } \\
\text { of my tiredness was gone } \\
\text { when we arrived in the } \\
\text { Sanur Beach.....after that, } \\
\text { we went to Nusa Dua } \\
\text { Beach... }\end{array}$ & $\begin{array}{l}\text { The text tells } \\
\text { about many } \\
\text { places visited by } \\
\text { the writer when } \\
\text { she had study } \\
\text { tour in Bali }\end{array}$ & Recount \\
\hline $\begin{array}{l}\text { Going to Central } \\
\text { Flores Island } \\
\text { p. } 53\end{array}$ & $\begin{array}{l}\text { At last holiday our family } \\
\text { went to Central Forest } \\
\text { Island of } \\
\text { Indonesia.... Kalimutu is } \\
\text { a volcano, close to the } \\
\text { town of Moni in Central } \\
\text { Forest Island of } \\
\text { Indonesia. }\end{array}$ & $\begin{array}{l}\text { The text tells } \\
\text { about many } \\
\text { places visited by } \\
\text { the writer when } \\
\text { she went to } \\
\text { Central Flores } \\
\text { Island }\end{array}$ & Recount \\
\hline $\begin{array}{l}\text { Visiting Raja } \\
\text { Ampat } \\
\text { p. } 65\end{array}$ & $\begin{array}{l}\text { I have an exciting } \\
\text { experience visiting Raja } \\
\text { Ampat...Raja Ampat has } \\
\text { beautiful scenery } \\
\text { especially of its } \\
\text { underwater corals and } \\
\text { beach... }\end{array}$ & $\begin{array}{l}\text { The text tells } \\
\text { about the write's } \\
\text { amazing moment } \\
\text { when visiting } \\
\text { Raja Ampat } \\
\text { Papua }\end{array}$ & Recount \\
\hline $\begin{array}{l}\text { Enjoyable } \\
\text { experience } \\
\text { p. } 71\end{array}$ & $\begin{array}{l}\text { Yesterday Budi's } \\
\text { classmates and I went to } \\
\text { visit five tourists objects } \\
\text { in Yogyakarta and its } \\
\text { surrounding e.g the } \\
\text { Sultan Palace, Tamansari } \\
\text { Water Castle.... }\end{array}$ & $\begin{array}{l}\text { The text tells } \\
\text { about the } \\
\text { enjoyable } \\
\text { experience in } \\
\text { Yogyakarta. The } \\
\text { writer visited any } \\
\text { places there. }\end{array}$ & Recount \\
\hline $\begin{array}{l}\text { National } \\
\text { monument } \\
\text { p. } 73\end{array}$ & $\begin{array}{l}\text { The National Monument } \\
\text { (or Monumen Nasional) } \\
\text { is a } 132 \text { metres tower in } \\
\text { the center of Merdeka }\end{array}$ & $\begin{array}{l}\text { The text } \\
\text { describes the } \\
\text { National } \\
\text { monument in }\end{array}$ & Descriptive \\
\hline
\end{tabular}




\begin{tabular}{|c|c|c|c|}
\hline Title & Sentence/ paragraph & The text is about & Text type \\
\hline & $\begin{array}{l}\text { Square, Central Jakarta. It } \\
\text { symbolizes the fight for } \\
\text { Indonesia's } \\
\text { independence... }\end{array}$ & $\begin{array}{l}\text { Jakarta. It is one } \\
\text { of the symbols of } \\
\text { Indonesian's } \\
\text { fight in } \\
\text { independence. }\end{array}$ & \\
\hline $\begin{array}{l}\text { Bunaken } \\
\text { p. } 85\end{array}$ & $\begin{array}{l}\text { Bunaken is one of the } \\
\text { very amazing places I } \\
\text { have ever visited..... } \\
\text { I am always amazed .... }\end{array}$ & $\begin{array}{l}\text { The text } \\
\text { describes the } \\
\text { beauty of } \\
\text { Bunaken which } \\
\text { can amaze } \\
\text { everyone }\end{array}$ & Descriptive \\
\hline $\begin{array}{l}\text { Taman Bunga } \\
\text { Nasional } \\
\text { p. } 100\end{array}$ & $\begin{array}{l}\text { The application of } \\
\text { sophisticated on } \\
\text { ornamental plants and } \\
\text { flowers results in the } \\
\text { invention of new varieties } \\
\text { and beautiful flowers... } \\
\text { The main purpose of this } \\
\text { project is oriented on } \\
\text { preparing the flowers... }\end{array}$ & $\begin{array}{l}\text { The text } \\
\text { describes the } \\
\text { reason and } \\
\text { purpose of the } \\
\text { Taman Bunga } \\
\text { Nasional }\end{array}$ & Descriptive \\
\hline $\begin{array}{l}\text { Toraja ceremony } \\
\text { p. } 103\end{array}$ & $\begin{array}{l}\text { The people of Toraja are } \\
\text { one of the } 350 \text { ethnics } \\
\text { group in Indonesia... } \\
\text { They still hold their } \\
\text { tradition. One example is } \\
\text { the funeral. }\end{array}$ & $\begin{array}{l}\text { The text } \\
\text { describes one of } \\
\text { ceremony done } \\
\text { by Toraja people }\end{array}$ & Descriptive \\
\hline $\begin{array}{l}\text { My vacation to } \\
\text { Solo } \\
\text { p. } 110\end{array}$ & $\begin{array}{l}\text { My family and I went on } \\
\text { recreation to Solo...on } \\
\text { Tuesday, we went to } \\
\text { Tawangmangu...the next } \\
\text { day, we went to } \\
\text { Kasunanan Palace.... }\end{array}$ & $\begin{array}{l}\text { The text tells the } \\
\text { writer's vacation } \\
\text { in Solo, some } \\
\text { places to visit }\end{array}$ & Recount \\
\hline $\begin{array}{l}\text { My interesting } \\
\text { holiday } \\
\text { p. } 119\end{array}$ & $\begin{array}{l}\text {....My family and I have } \\
\text { just returned from an } \\
\text { interesting holiday at } \\
\text { Lake Maninjau near } \\
\text { Padang..... we had a two } \\
\text { hour trip to Bukit } \\
\text { Tinggi... }\end{array}$ & $\begin{array}{l}\text { The text tells the } \\
\text { writer's holiday } \\
\text { in Padang, some } \\
\text { places to visit }\end{array}$ & Recount \\
\hline
\end{tabular}




\begin{tabular}{llll}
\hline \multicolumn{1}{c}{ Title } & \multicolumn{1}{c}{ Sentence/ paragraph } & The text is about & Text type \\
\hline $\begin{array}{l}\text { Baliem festival } \\
\text { p. } 120\end{array}$ & $\begin{array}{l}\text { The name Baliem comes } \\
\text { from the name of a valley } \\
\text { in the central highlands of } \\
\text { Papua, Baliem valley. }\end{array}$ & $\begin{array}{l}\text { The text } \\
\text { describes how } \\
\text { Baliem festival } \\
\text { done by the } \\
\text { society in Papua }\end{array}$ & Descriptive \\
& & \\
& $\begin{array}{l}\text {..the main event is a war } \\
\text { between tribes. However, } \\
\text {.. Baliem festival is full } \\
\text { of peaceful faces and } \\
\text { brings joy and fun... }\end{array}$ & \\
\hline
\end{tabular}

\subsection{Story}

The book gives some Indonesian's stories. This can introduce its folklore. By learning it, it leads the students to recognize the diversity and catch the moral value which is applied in the daily life. These texts included into the Narrative texts. Here are the following texts:

\begin{tabular}{|c|c|c|}
\hline Title & Summary & Moral Value \\
\hline $\begin{array}{l}\text { Rabbit and crocodile } \\
\text { p. } 22\end{array}$ & $\begin{array}{l}\text { Rabbits wanted to cross river. He asked } \\
\text { the crocodiles to make line and he wanted } \\
\text { to count the kind crocodile. At last, he } \\
\text { could pass the river. }\end{array}$ & $\begin{array}{l}\text { Helping each } \\
\text { other }\end{array}$ \\
\hline $\begin{array}{l}\text { The History of } \\
\text { Tanjung Lesung } \\
\text { p. } 49\end{array}$ & $\begin{array}{l}\text { There was a traveler named Raden Budog } \\
\text { tried to find out a beautiful girl in his } \\
\text { dream. He arrived in the village } \\
\text { (Kampung esung) and met her. They got } \\
\text { married. Raden Budog pounded rice in } \\
\text { Friday which is allowed since it is the } \\
\text { time to pray. At last, he turned into } \\
\text { monkey. }\end{array}$ & $\begin{array}{l}\text { Be obedient } \\
\text { with the } \\
\text { regulations } \\
\text { where we live }\end{array}$ \\
\hline $\begin{array}{l}\text { The History of } \\
\text { Cenderawasih } \\
\text { p. } 63\end{array}$ & $\begin{array}{l}\text { There were } 2 \text { birds (Mr. and Mrs. } \\
\text { Brown). Mr Brown was jealous with Mr. } \\
\text { Green which had beautiful feathers. At } \\
\text { last, Mr. Brown asked to the God to } \\
\text { change him to be beautiful. He turned } \\
\text { into beautiful but he was rejected by his } \\
\text { wife since it made them in danger } \\
\text { because he would be hunted. He was } \\
\text { away in sadness. }\end{array}$ & $\begin{array}{l}\text { Be grateful with } \\
\text { what we have }\end{array}$ \\
\hline $\begin{array}{l}\text { Red feather } \\
\text { p. } 86\end{array}$ & $\begin{array}{l}\text { There was a fox caught a hen (red } \\
\text { feather). The fox saw a dove and wanted } \\
\text { to catch her too to have double dinner. }\end{array}$ & Don't be greedy \\
\hline
\end{tabular}




\begin{tabular}{|c|c|c|}
\hline & $\begin{array}{l}\text { The dove knew if the fox caught her } \\
\text { friend, a hen, so she pretended to have } \\
\text { broken wing. The fox run to her, but she } \\
\text { flew away. The fox suddenly realized that } \\
\text { the hen was also away. The fox got } \\
\text { nothing to dinner. }\end{array}$ & \\
\hline $\begin{array}{l}\text { The story of } \\
\text { Pungguk } \\
\text { p. } 110\end{array}$ & $\begin{array}{l}\text { There was a poor good looking man } \\
\text { named Pungguk. He was falling in love } \\
\text { with Princess Purnama Bulan who had } \\
\text { fiancé. She gave him a veil. When he } \\
\text { went to the country road, Purnama } \\
\text { Bulan's fiancé saw the veil and thought } \\
\text { that he stole it. Suddenly the boy killed } \\
\text { Pungguk but in his body grew mushroom, } \\
\text { and he turned into bird. The bird was used } \\
\text { to sit in the highest branch to see the full } \\
\text { moon. }\end{array}$ & $\begin{array}{l}\text { Be faith with } \\
\text { yours, or you } \\
\text { will make } \\
\text { someone in a } \\
\text { danger }\end{array}$ \\
\hline $\begin{array}{l}\text { The story of } \\
\text { Banyuwangi } \\
\text { p. } 125\end{array}$ & $\begin{array}{l}\text { There was a prince (Raden Banterang) } \\
\text { married with beautiful princess. On one } \\
\text { night, her brother gave her "keris" and } \\
\text { asked her to kill Raden Banterang. He put } \\
\text { it in her bed. Raden Banterang knew it } \\
\text { and thought that his wife would kill him. } \\
\text { To prove this, his wife jumped into the } \\
\text { river. If the river was fragrance, it meant } \\
\text { that she was honest. Raden Banterang } \\
\text { was so upset since he did not believe his } \\
\text { wife. }\end{array}$ & $\begin{array}{l}\text { What actually } \\
\text { seen does not } \\
\text { always what } \\
\text { actually } \\
\text { happened }\end{array}$ \\
\hline
\end{tabular}

There are 18 texts provide the Indonesian description and moral value. They are written in Descriptive, Recount, and Narrative text. It could be counted that $18,5 \%$ texts in the book contain Indonesian description and moral value.

\section{CONCLUSION}

Indonesia is a country which is full of diversity. The insertion of local wisdom in education will help the students to aware and love their country. The book titled Prediksi UN SMP Bahasa Inggris published by Graha Pustaka Jakarta portrayed Indonesian through the English genre text. There are 97 text, 18 texts (18,5\%) of them give the description and story containing local wisdom (Indonesian moral value). These description and moral value are important in education to build the students' nationality.

\section{REFERENCES}

Ary, D., Jacobs, L. C., \& Sorensen, C. K. (2010). Introduction to Research in Education (Eighth ed.). Belmont, CA: Wadsworth.

Brown, H. Douglas. 2000. Teaching by Principles. England: Longman 
http://news.metrotvnews.com/peristiwa/PNg4Oj7b-isu-sara-pilkada-dkidinilai-menjalar-ke-sektor-pendidikan accessed on August, $14^{\text {th }} 2017$

http://www.ef.co.id/englishfirst/englishstudy/bahasa-inggris/jenis-jenis-teksdalam-bahasa-inggris.aspx accessed on August, $15^{\text {th }} 2017$

http://www.kompasiana.com/wiwaha/krisis-sara-di-pemilukada-2017

581c3518577b61367e35ed46 accessed on August, $14^{\text {th }} 2017$

https://en.oxforddictionaries.com/definition/local accessed on August, $14^{\text {th }}$ 2017

https://en.wikipedia.org/wiki/Wisdom accessed on August, $14^{\text {th }} 2017$

Komara, Endang. 2017. A journal of LocalWisdom Based Learning

Mungmachon, Roikhwanphut. Knowledge and Local Wisdom: Community Treasure. International Journal of Humanities and Social Science Vol. 2 No. 13; July 2012. 174. PhD Candidate in Integral Development Studies. Ubon Ratchathani University, Thailand 